\title{
تمرينات مقترحة لتدريب الإصبع الرابع (الخِنْصَر) على مهارة الزحلقة لأداء مسافة النصف تون على آلة العود (glissando)
}

\author{
د/ داليا عماد الدين سلامة المصري

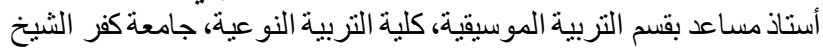

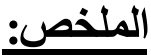

بالرغم من شيوع استخدام الزحلقة (glissando) بالإصبع الر ابع بين جموع عازفي آلة العود

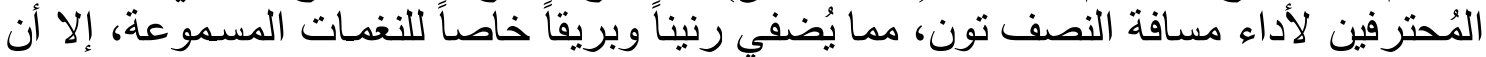

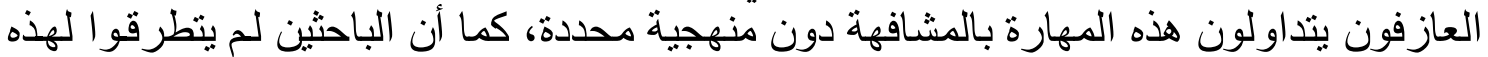

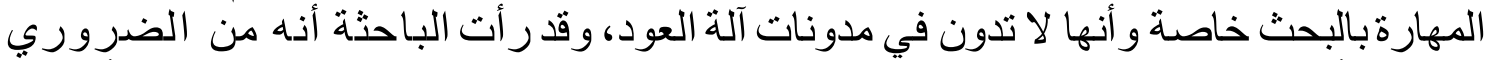

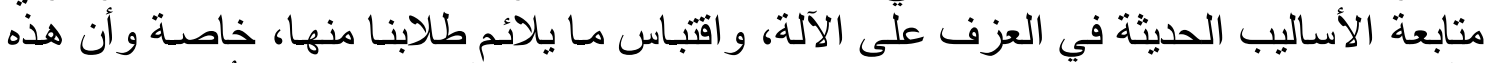

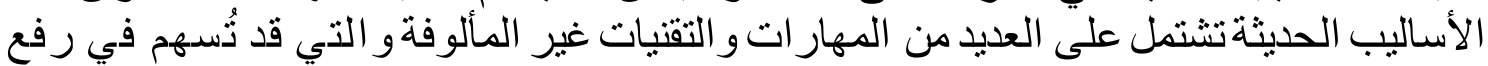

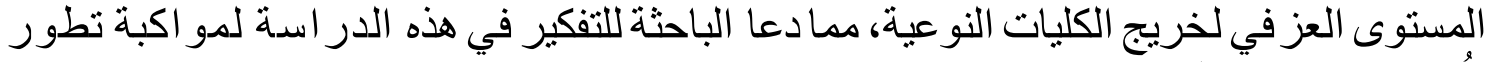

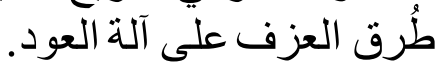

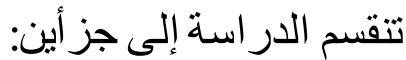
أو لا: الإطار النظري ويتضمن:

$$
\begin{aligned}
& \text { - در اسات سابقة. } \\
& \text { - آلة العود وبعض المهار ات العزفية للكآلة. } \\
& \text { ثانيا: الإطار التطبيقي ويتضمن: }
\end{aligned}
$$

- وضع أربعةتدريبات تكنيكية من قِبل الباحثة لتدريب الإصبع الر ابع على مهارة الز حلقة

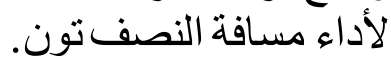

- وضع سبعةتمرينات لحنية مقترحة من قِبل الباحثةتنتنمل على مهارة الزحلقة لأداء مسافة

$$
\text { النصف تون باستخدام الإصبع الر ابع. }
$$

- توظيف هذه المهارةو الاستفادة منها في عزف أجز اء لحنية من لونجا حجاز كار كار (حسين

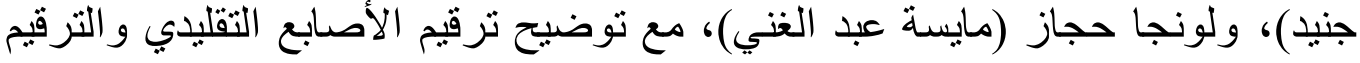

$$
\text { الجديد باستخدام الز حلقة بالإصبع الر ابع. }
$$

و اختُتم البحث بالنتائج و التوصيات، ثم قائمة المر اجع وملخص البحث.

مقدمة:

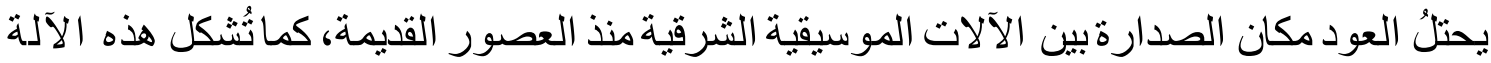

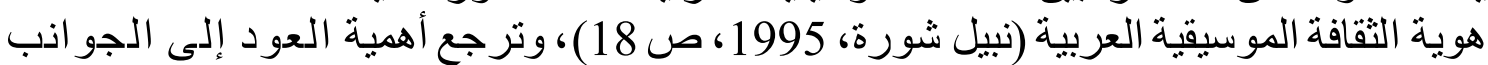

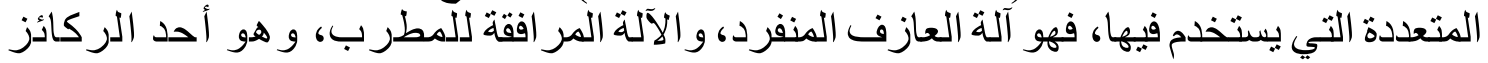

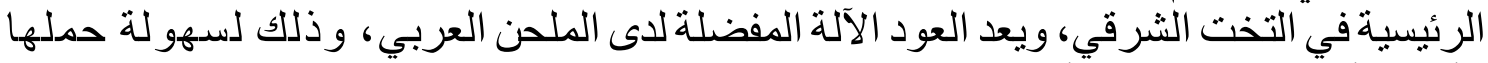

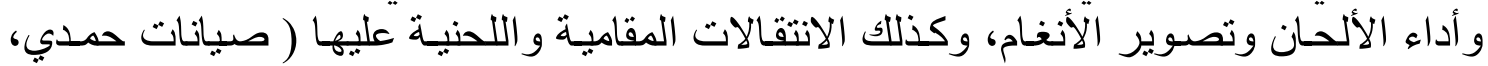
.1978) 1978 (19)

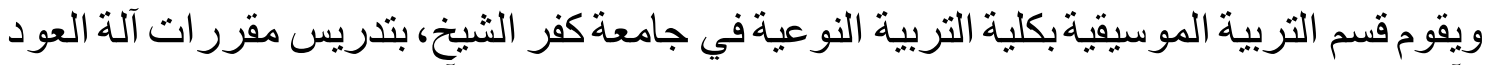

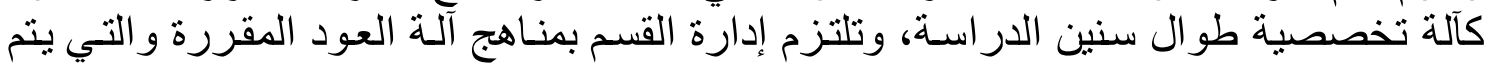


تدريسها في كلية التربية الموسيقية بجامعة حلو ان، باعتبار ها الكلية الأمو التي نستقي من أساتذتها

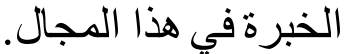

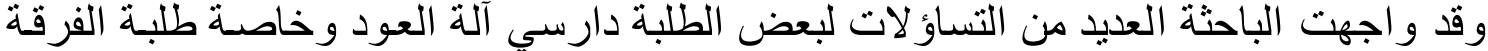

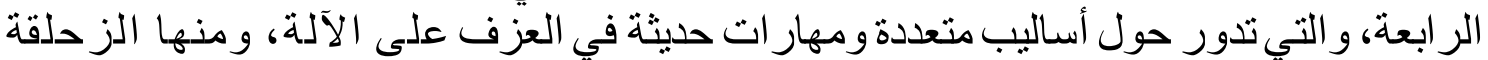
(glissando)

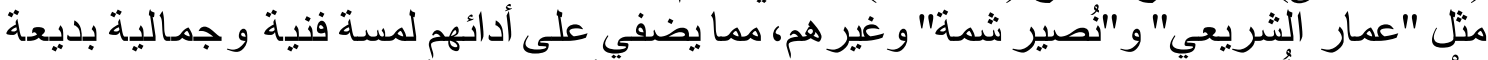

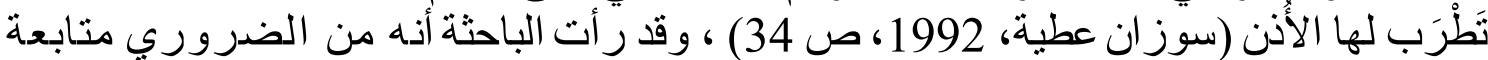

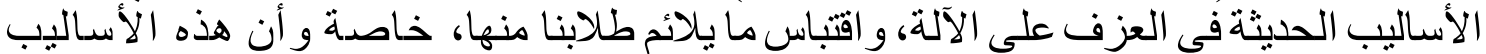

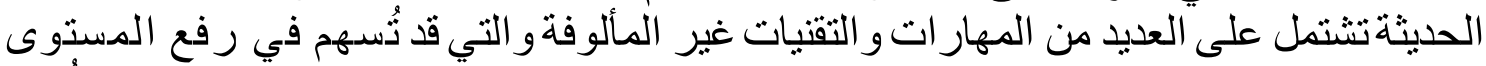

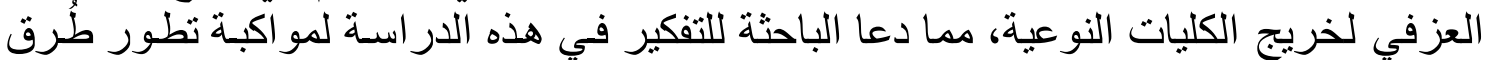

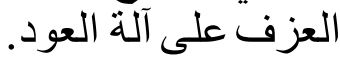

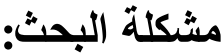

بالرغم من شيوع استخدام الزحلقة بالإصبع الرابع بين جموع عازفي في آلة العود المُحترفين لأداء

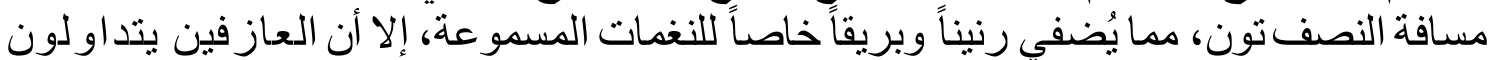

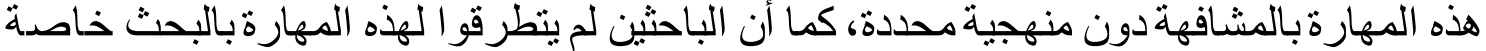

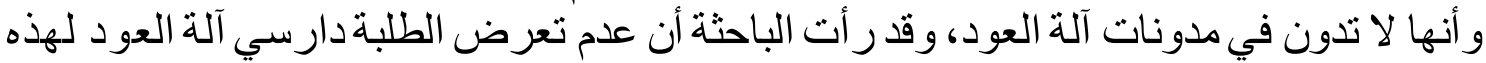

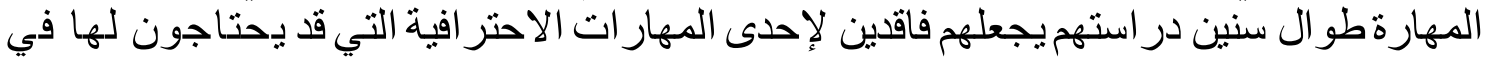

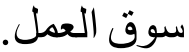

ويمكن صياغة مشكلة البحث في الأسئلة التالية.

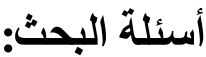

1. كيف يمكن وضع تمرينات تكنيكية لتدريب الإصبع الر ابع على مهارة الزحلقة لأداء مسافة

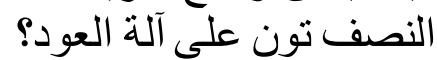
2. كيف يمكن وضع تمرينات لحنية مقترحة تشتمل على مهارة الزحلقة لأداء مسافة النصف

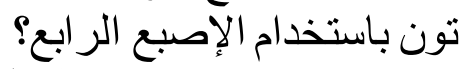

3. كيف يمكن الاستفادة من هذه المهارة في عزف بعض المؤلفات الموسيقية المعروفة؟

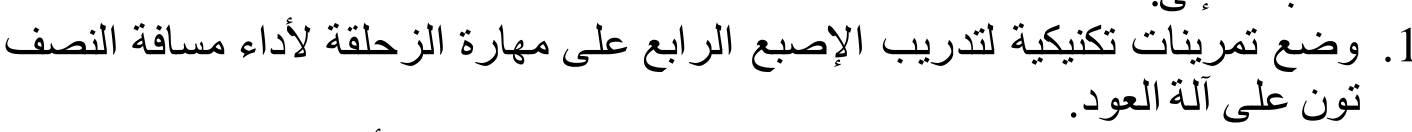

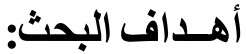

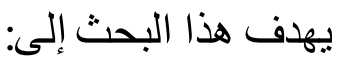
2. وضع تمرينات لحنية مقترحة تشتمل على مهارة الزحلقة لأداء مسافة النصف نون

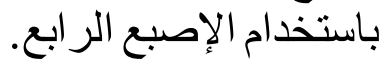
3. توظيف هذه المهارة و الاستفادة منها في عزف بعض المؤلفات الموسيقية المعروفة. تكمن أهمية البحث في فكرة انصهار الحدود بين الطُرق التقليدية في العزف على آلة العود و الطرق

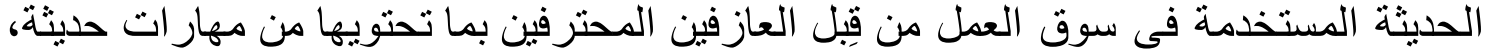

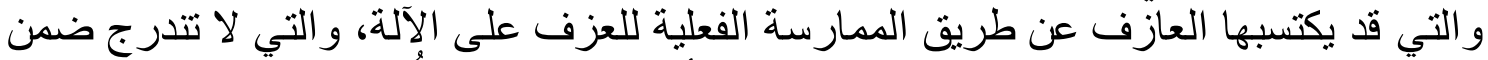

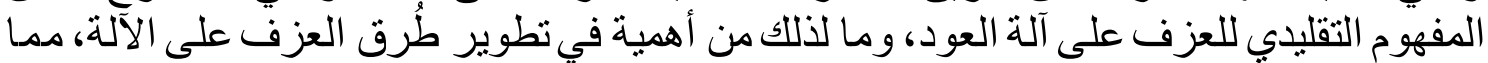
يؤدي إلى تحسين مستوى عاز في آلة العود من خريجي الكليات النو عية النتخصصة. 


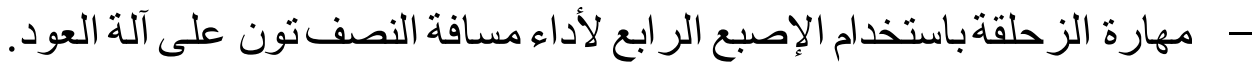

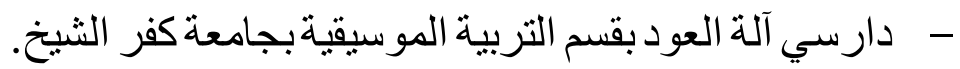

$$
\begin{aligned}
& \text { عينة البحث: اختارت الباحثةنموذجين من قالب اللونجا: } \\
& \text { 1. لونجا حجاز كار (حسين جنيد). } \\
& \text { 2. لونجا حجاز (مايسة عبد الغني). }
\end{aligned}
$$

مصطلحات البحث: - (الزة

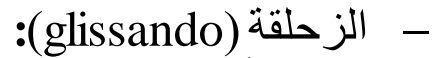

انز لاق أو زحلقة الإصبع على أوتار الآلات الوترية الغربية أو الشرقية، بين نغنتين بينهما

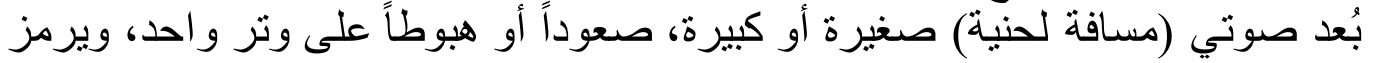

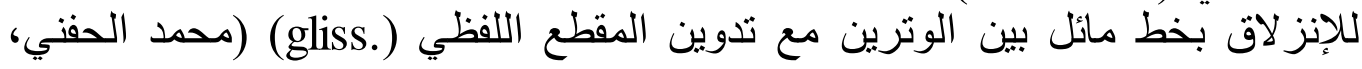

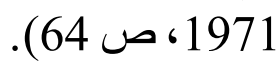

$$
\text { - }
$$

هو البراعة الميكانيكية الناتجة عن السيطرة على أعضاء الجسم و التحكم في استخدام

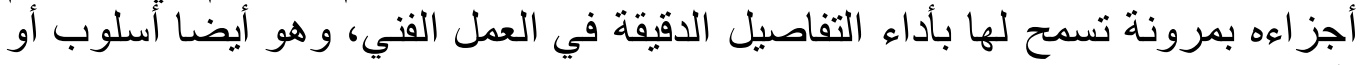

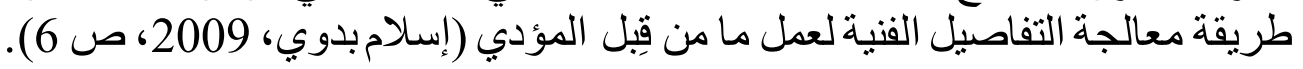
-

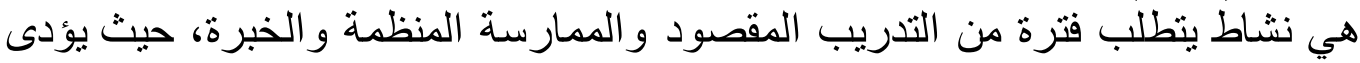

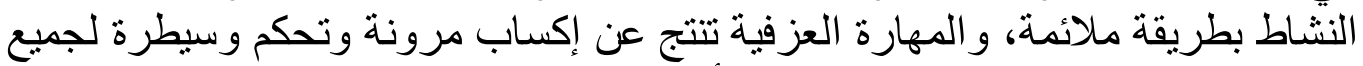

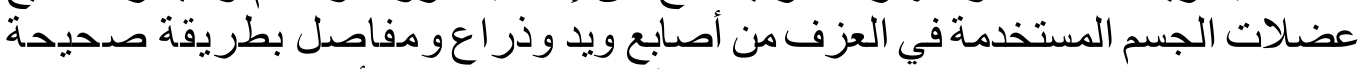
لعزف مقطو عات موسيقية بطريقة فنية سليمة (آمال صادق و و فؤ اد أبو حطب، 1992 الع ص ص

$$
\begin{aligned}
& \text { تنقسم الدراسة إلى جزأين: } \\
& \text { أولا: الإطار النظري ويتضمن: } \\
& \text { - - د در اسات سابقة. } \\
& \text { - آلة العود وبعض المهار ات العزفيةل للآلة. } \\
& \text { ثاتيا: الإطار التطبيقي ويتضمن: }
\end{aligned}
$$

- - وضع أربعة تدرييات تكنيكية من قِبل الباحثة لتدريب الإصبع الر ابع على مهارة الزحلقة

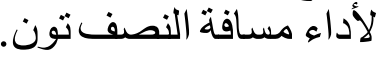

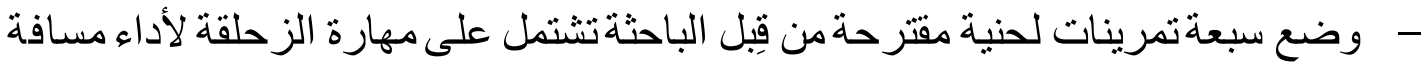
النصف تون باستخدام الإصبع الر ابع.

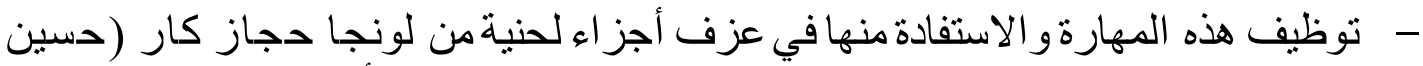

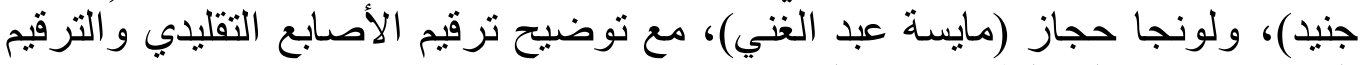
الجديد باستخدام الزحلقة بالإصبع الر ابع. 
قدم علي عبد الودود (1995) در اسة بعنوان "إمكانية عزف الكروماتيك و المقامـات العربية في

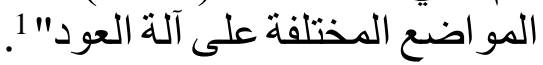

تتاولت الدر اسة إمكانية عزف الكروماتيك و المقامات العربية في المو اضع المختلفة على آلة العو د،

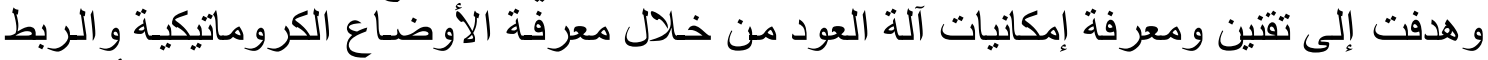

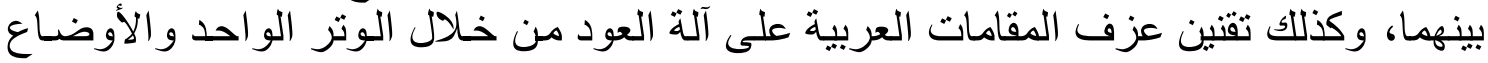

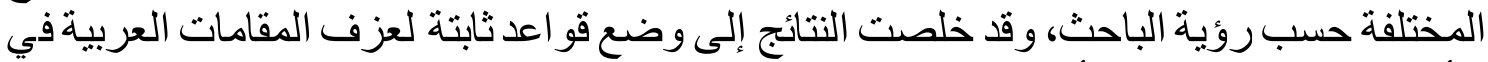
الأوضاع المختلفة غير المألوفة، على الآلة وحل بعض المشكلات المّلات التكنيكية.

تتفق تللك الدراسة مع البحث الحالي في الاهتمام بالأساليب غير التقليدية في الأداء على آلة العود ده،

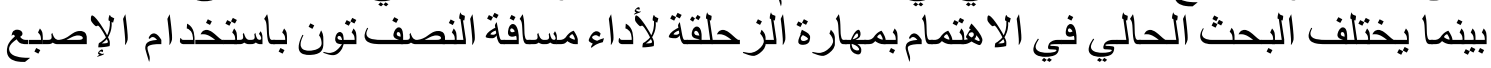

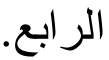

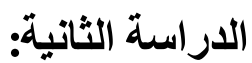
قدم محمد أحمد هشام (2004) در اسة بعنو ان "تذليل الصعوبات في بعض معزوفات آلة العود بمنهج الفرقة لر ابعة (البكالوريوس)" (2004)

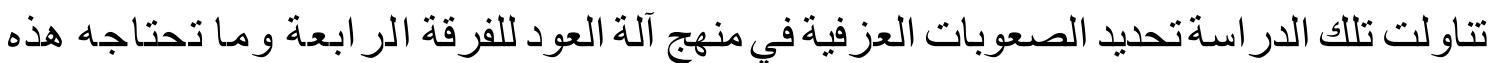

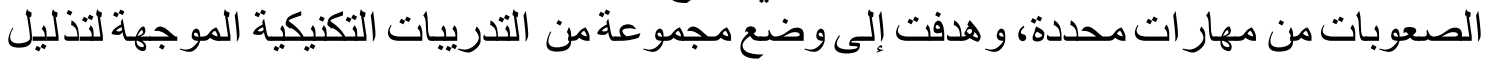

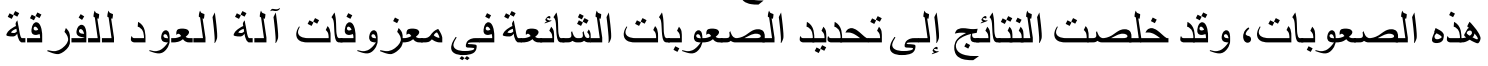
الر ابعة و ابتكار تدرييات تقنية للتغلب عليها.

تتفق تلك الدر اسة مع البحث الحالي في الاهتمام بدارسي آلة العود بالكليات النوعية ومهار اتهم

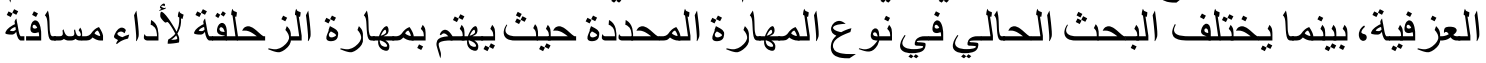
النصف تون باستخدام الإصبع الر ابع.

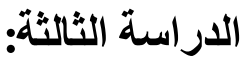

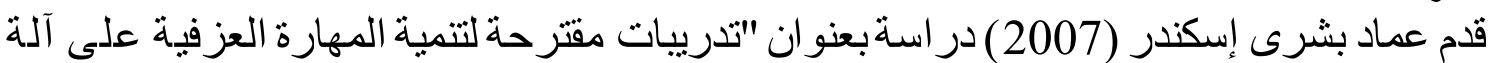

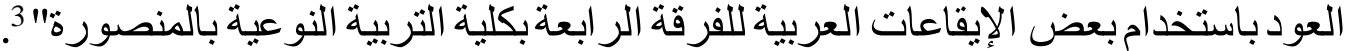

تتاولت تللك الدر اسة تحليل للمقرر ات العزفية لآلة العود لجميع الفرق الدر اسية ومن خلال الدر اسة

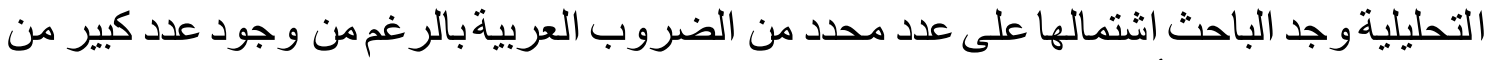

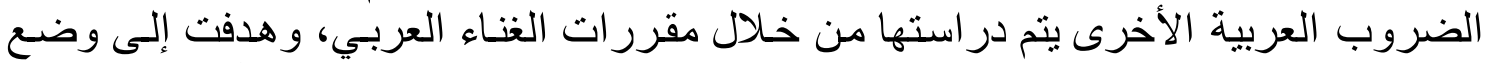

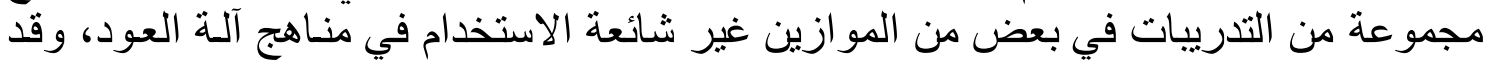

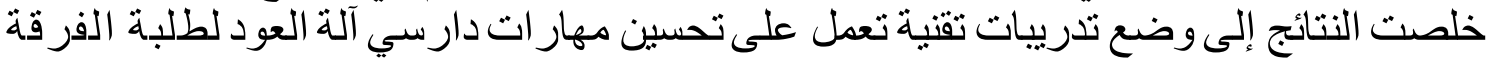

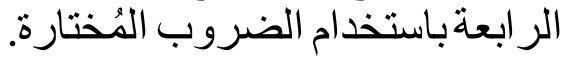

1 1 علي عبد الودود، 1995، بحث منشور، مجلة علوموفنون، المجلد السابع، كلية التربية الموسيقية، جامعة حلو ان، القاهرة.

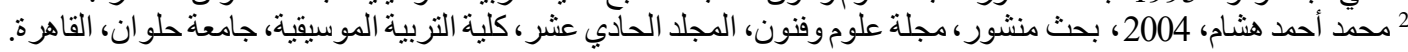

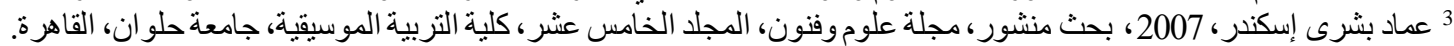

Journal of Specific Education and Technology (Scientific and applied research) - Issued by Faculty of Specific Education - Kafrelsheikh University -Egypt 
تتفق تلك الدراسة مع البحث الحالي في استخدام المنهج الوصفيوفي الاهتمام بتتمية المهارات

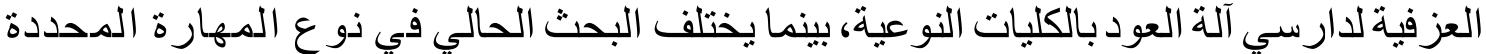

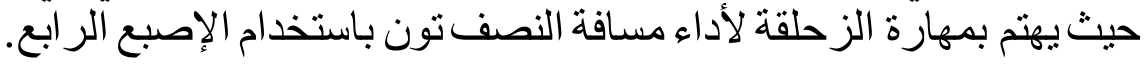

آلة العود وبعض المهارات العزفية للآلة:

أخذت آلة العود في التقام و الرقي بفضل أساتذة ورو اد الآلة في مصر و والعالم العربي ومنهم رياض

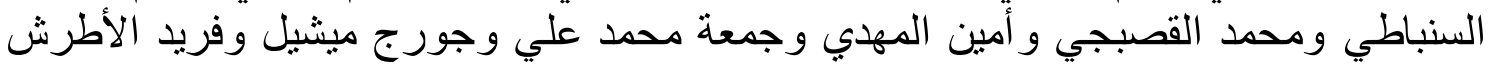

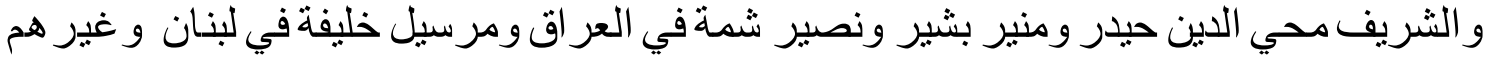

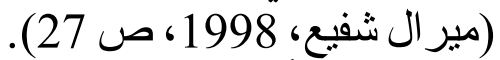

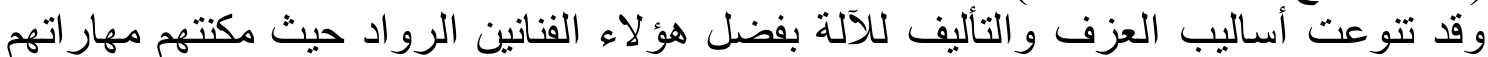

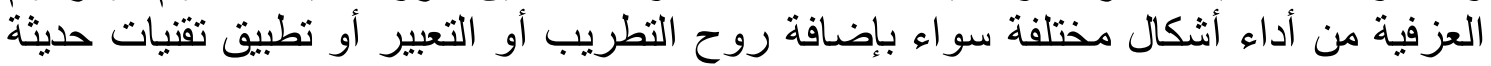

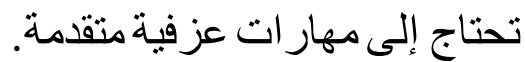

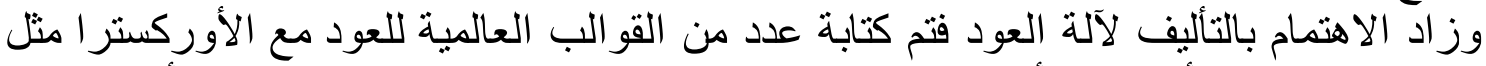

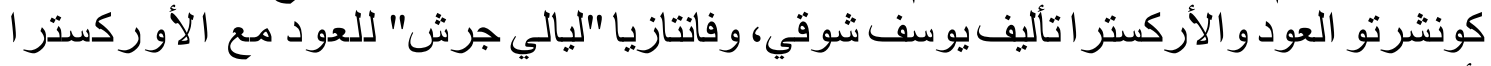

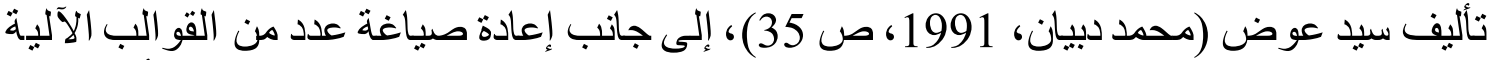

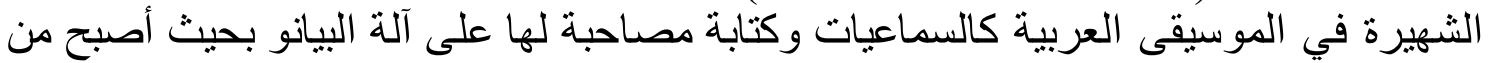

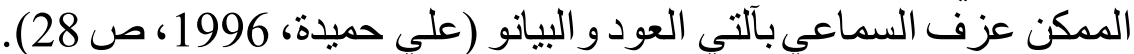

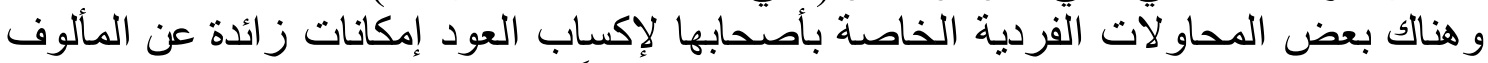

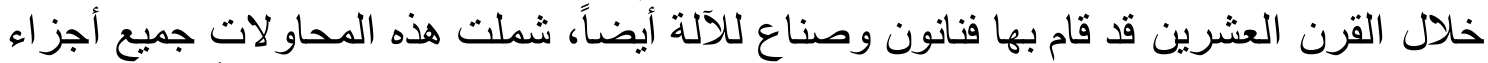

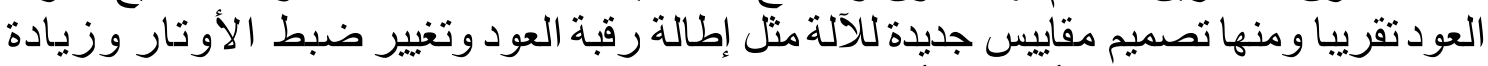

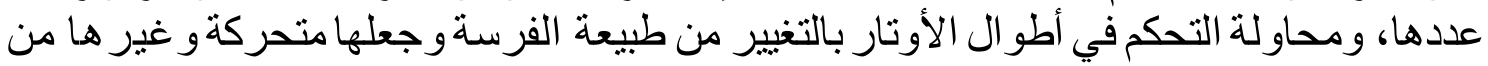

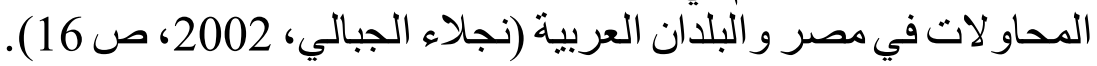

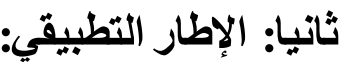

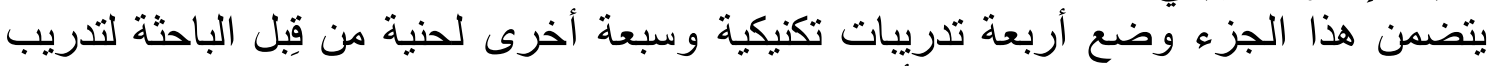

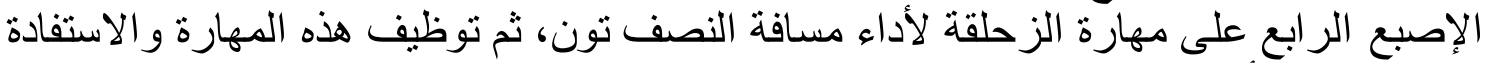

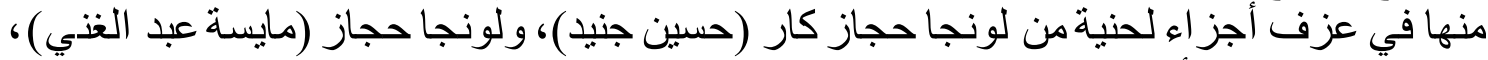
مع توضيح ترقيم الأصابع التقليدي و الترقيم الجديد باستخدام الزحلقة بالإصبع الر ابع.

1.

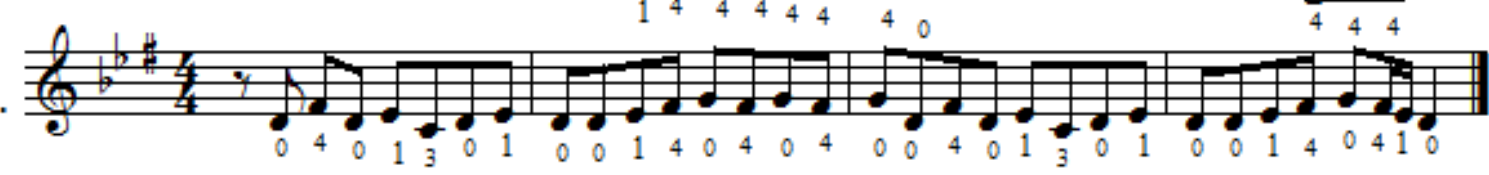

- - يهذف التمرين الأول إلى تدريب الإصبع الر ابع على أداء مهارة الزحلقة على وتر (الدوكاه) في مقام الحجاز .

* ر اعت الباحثة استخدام بعض المقامات شائعة الاستخدام في سوق العمل، ويلاحظتدوين أرقام الأصابع بالثكل التقليدي أسفل النغمات، بينما يدون الترقيم الجديد باستخدام الزحلقة أعلى النغمات.

Journal of Specific Education and Technology (Scientific and applied research) - Issued by Faculty of Specific Education - Kafrelsheikh University -Egypt 
2 .

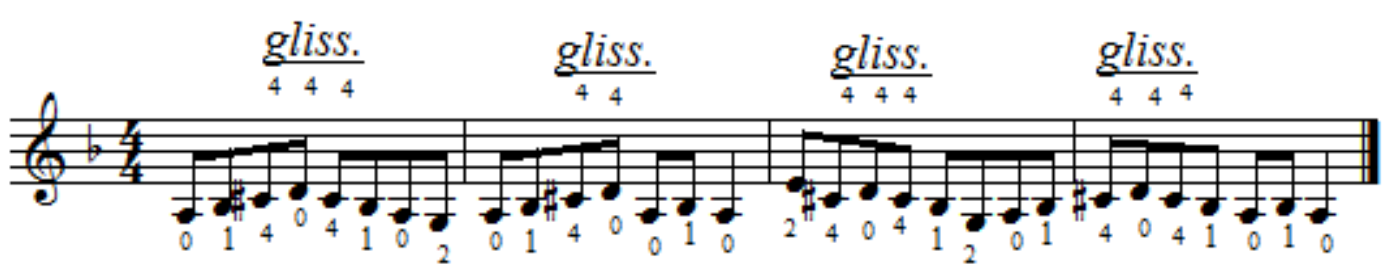

- يهدف التمرين الثناني إلى تدريب الإصبع الر ابع على أداء مهارة الزحلقة على وتر (العُشير ان) في مقام الحجاز المصور على درجة العُشيران.

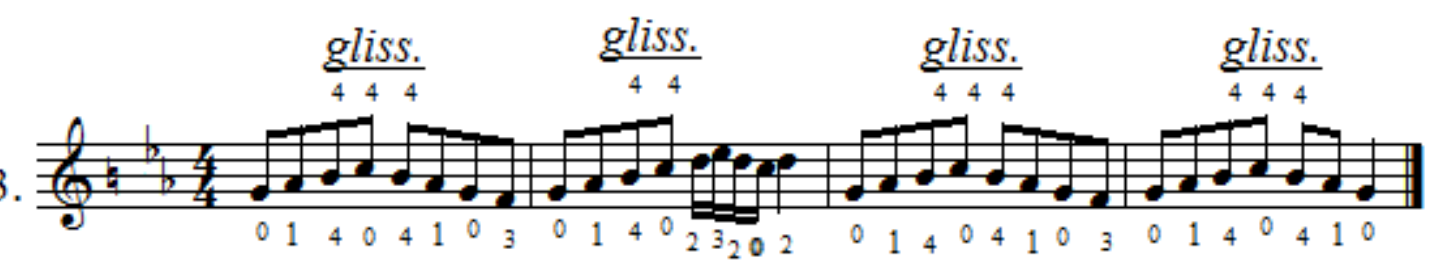

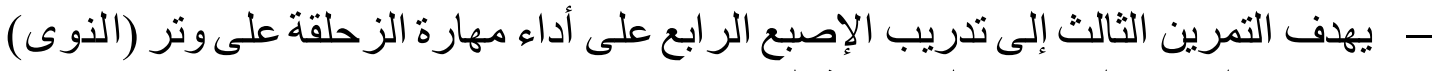

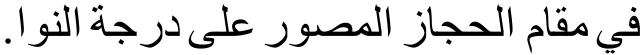

4.

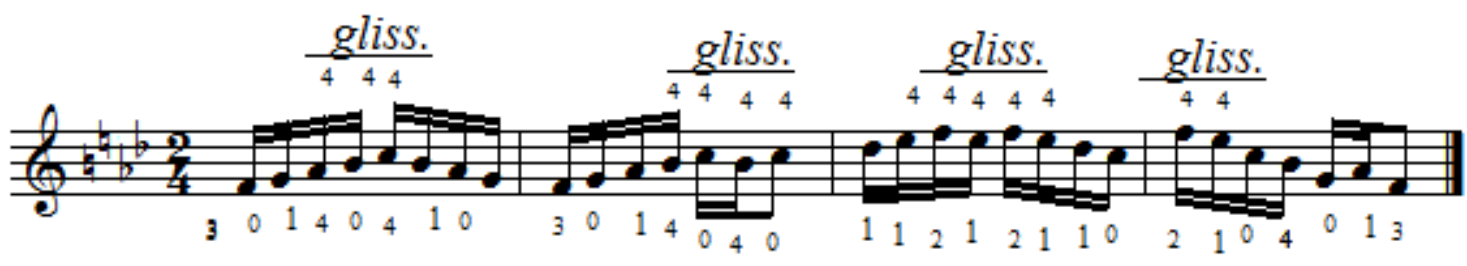

- - يهذف التمرين الر ابع إلى تدريب الإصبع الر ابع على أداء مهارة الزحلقة على وتر (الذو ا )

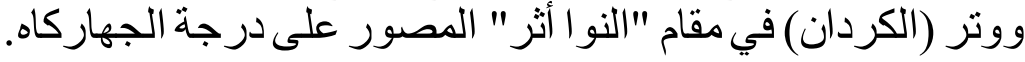




\section{التمرين الأول}

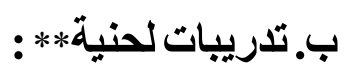

Oud
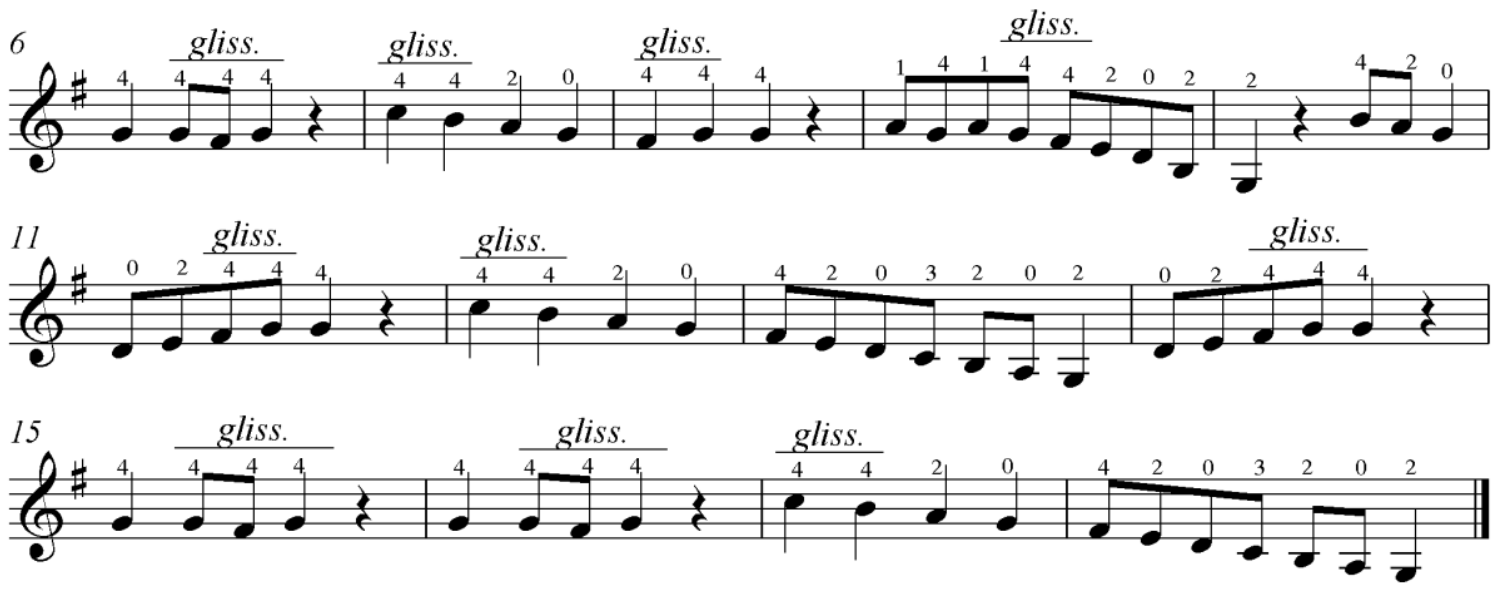
يهذف التمرين الأول إلى:

1. تدريب الإصبع الر ابع على أداء مهارة الزحلقة بين نغنتي (المساهور و الكردان) ونغنتي (الحجاز و النوى) صعوداً ولثبوطاً.

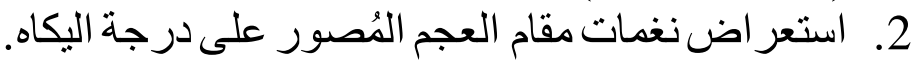
التمرين الثاني

Oud
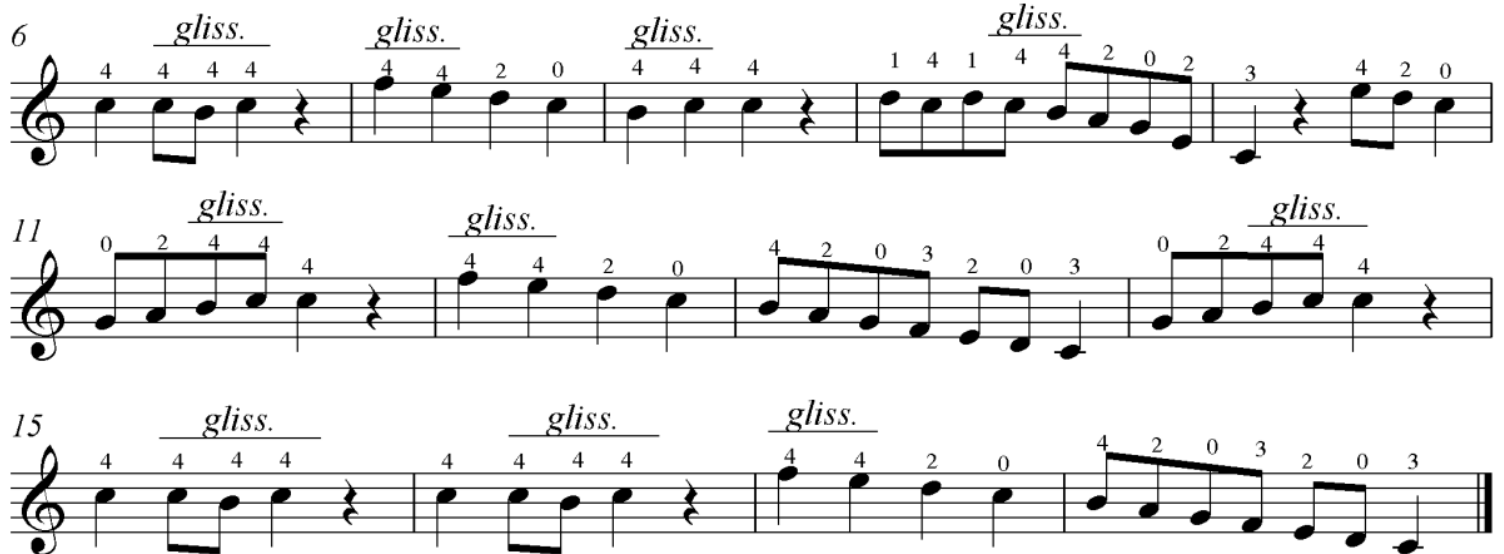

** راعت الباحثة استخدام بعض المقامات شائعة الاستخدامفي سوق العمل، ويلاحظتدوين أرقام الأصابع بالثكل التقليدي أسفل النغمات،

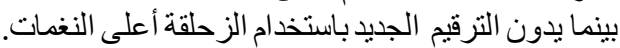

Journal of Specific Education and Technology (Scientific and applied research) - Issued by Faculty of Specific Education - Kafrelsheikh University -Egypt 
1. تدريب الإصبع الر ابع على أداء مهارة الزحلقة بين نغنتي (جواب البوسليك و المـاهوران) ونغنتي (الماهور و الكردان) صعوداً و هبوطاً. 2. استعر اضنغمات مقام العجم المصور على دالى درجة الر است (التبريز ).
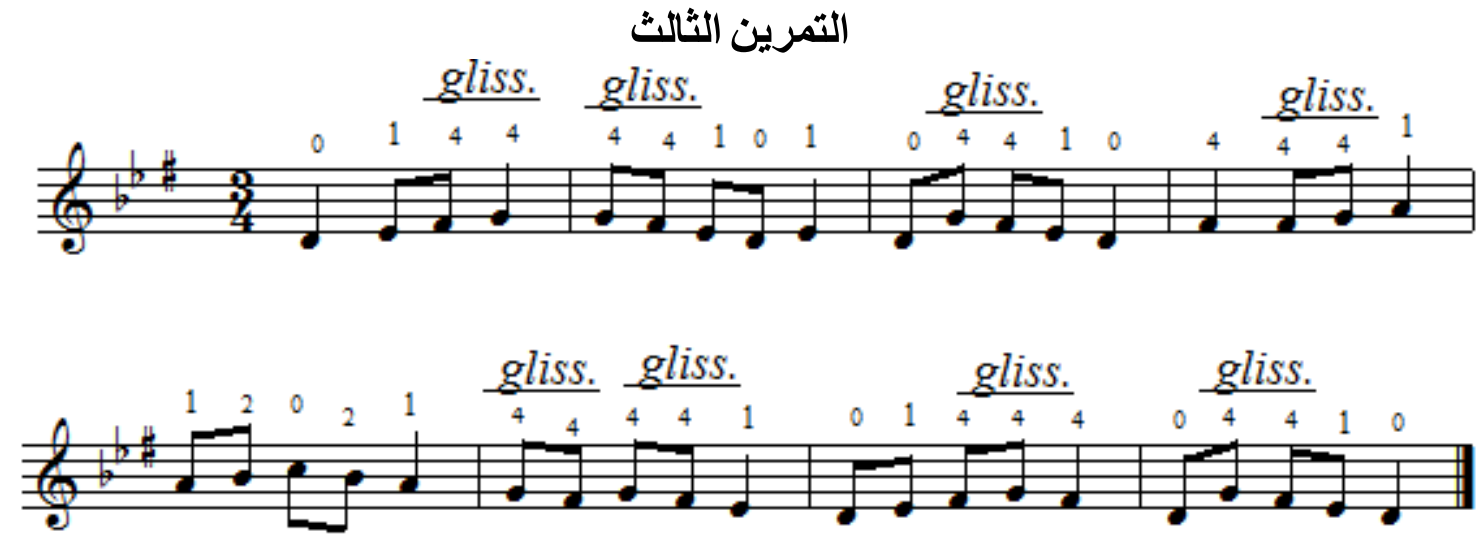

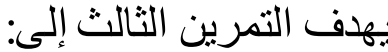
1. تدريب الإصبع الر ابع على أداء مهارة الزحلقة بين نغنتي (الحجاز و النوى) صعوداً وهبوطاً.

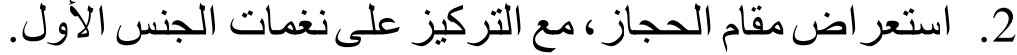
التمرين الرابع الجنات

Oud
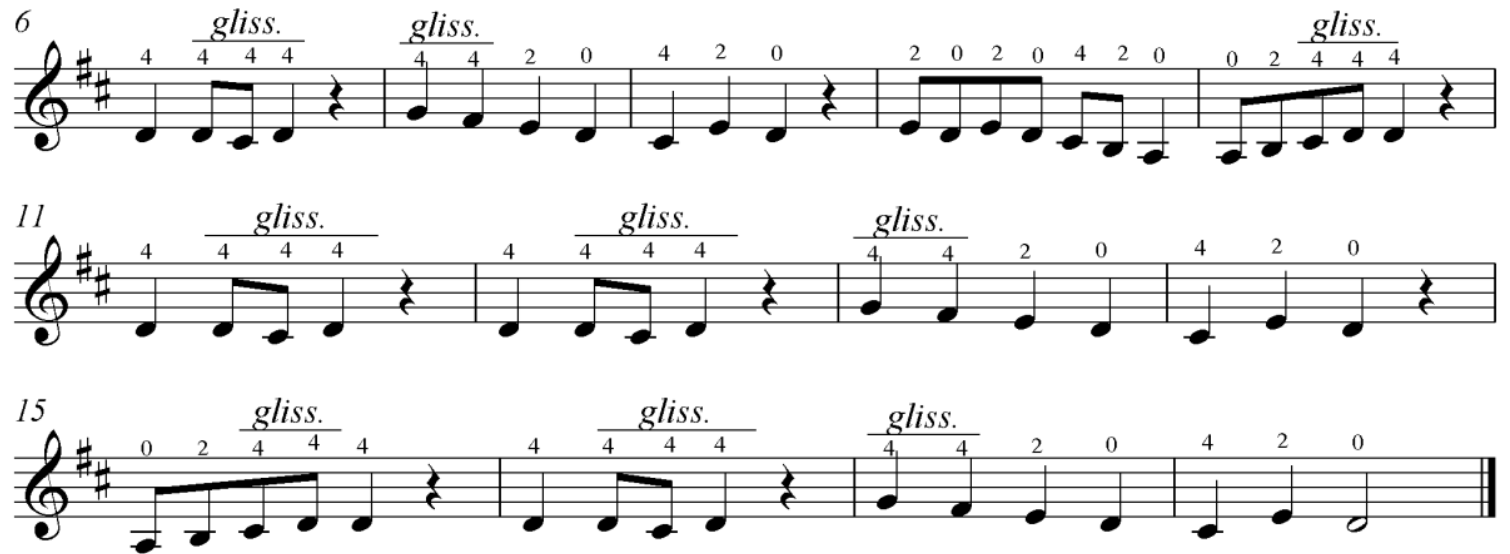

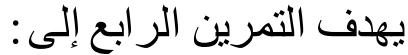

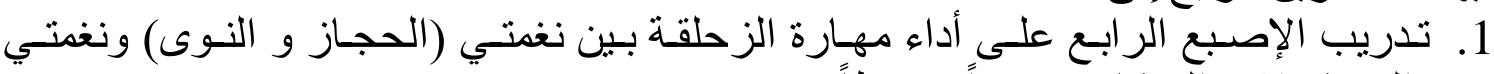
(الزيركو لاهو الدوكاه) صعوداً وهبوطاً.

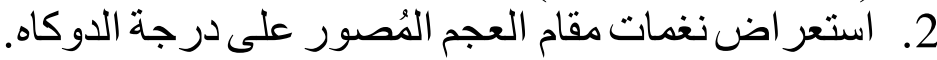


التمرين الخامس
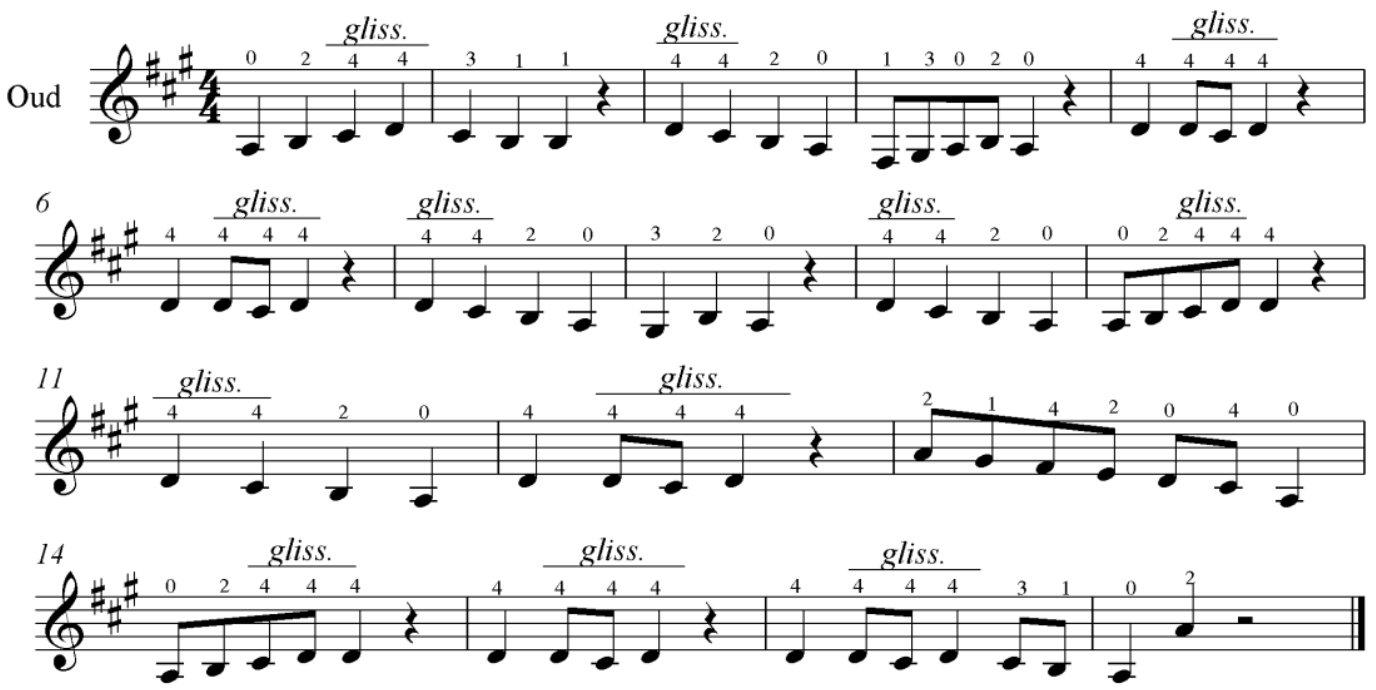

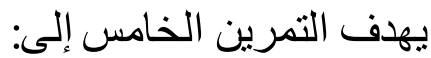

1. تدريب الإصبع الر ابع على أداء مهارة الزحلقة بين نغنتي (الزيركو لاهو والدوكاه) صعوداً و هبوطاً. 2. استعر اض نغمات مقام العجم الئصور على درجة الحسيني.

التمرين السادس

Oud
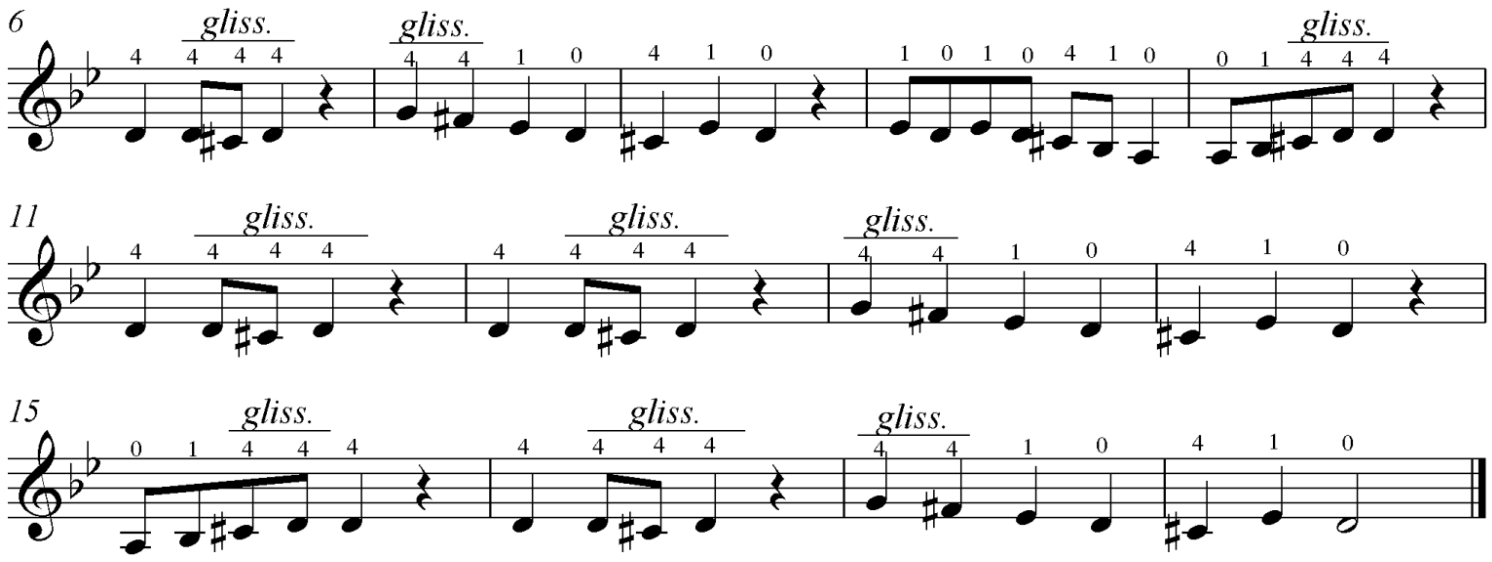

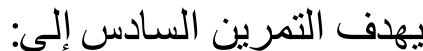

1. تدريب الإصبع الر ابع على أداء مهارة الزحلقة بين نغنتي (الحجاز و النوى) صعوداً وهبوطاً. 2. 2. استعر اض نغمات مقام الثهيناز. 


$$
\text { التمرين السابع }
$$
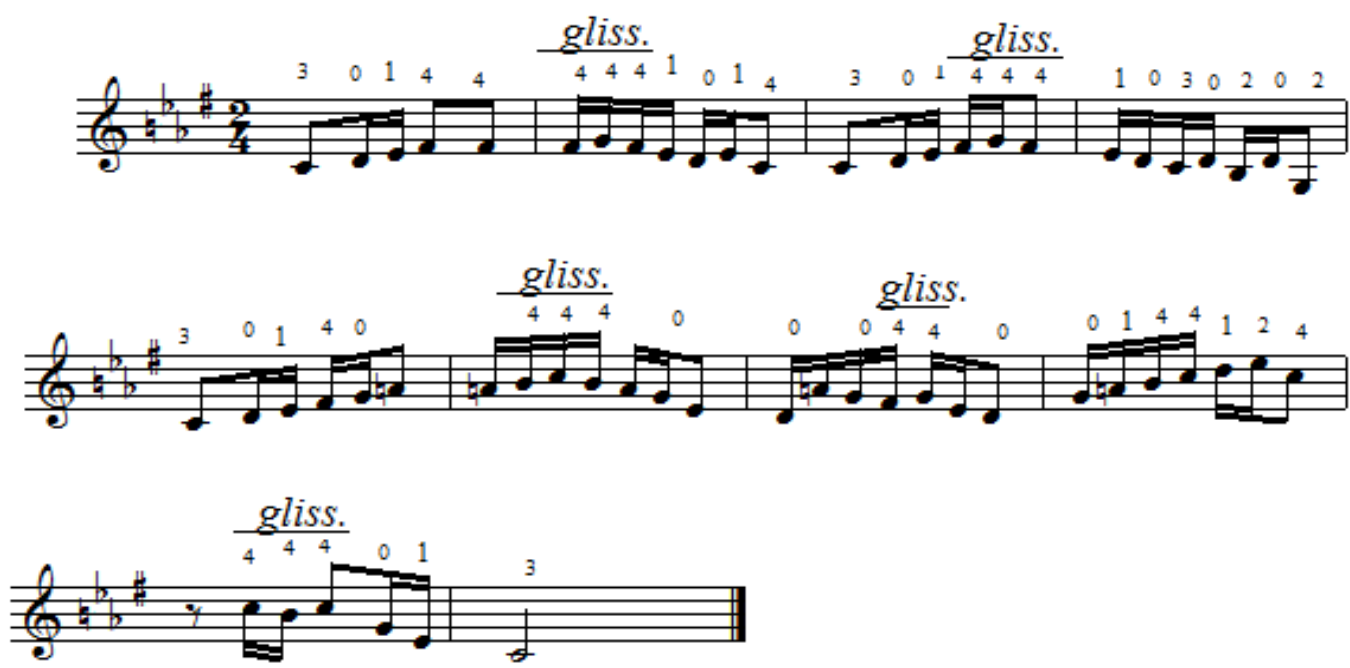

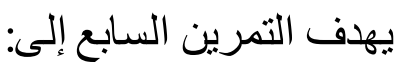

1. تدريب الإصبع الر ابع على أداء مهارة الزحلقة بين نغنتي (الحجاز و النوى) ونغمتي (الماهور و الكردان) صعوداً وهبوطاً. 2. استعر اض نغمات مقام النو ا أثر مع التركيز على نغمات العِقْ الأول من المقام.

ج. توظيف مهارة الزحلقة بالإصبع الرابع في بعض المؤلفات الموسيقية:

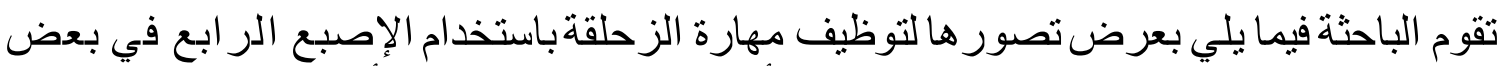

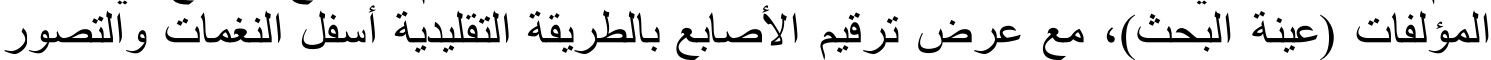
للترقيم الجديد باستخدام مهارة الزحلقة أعلى النقلى النغمات. 

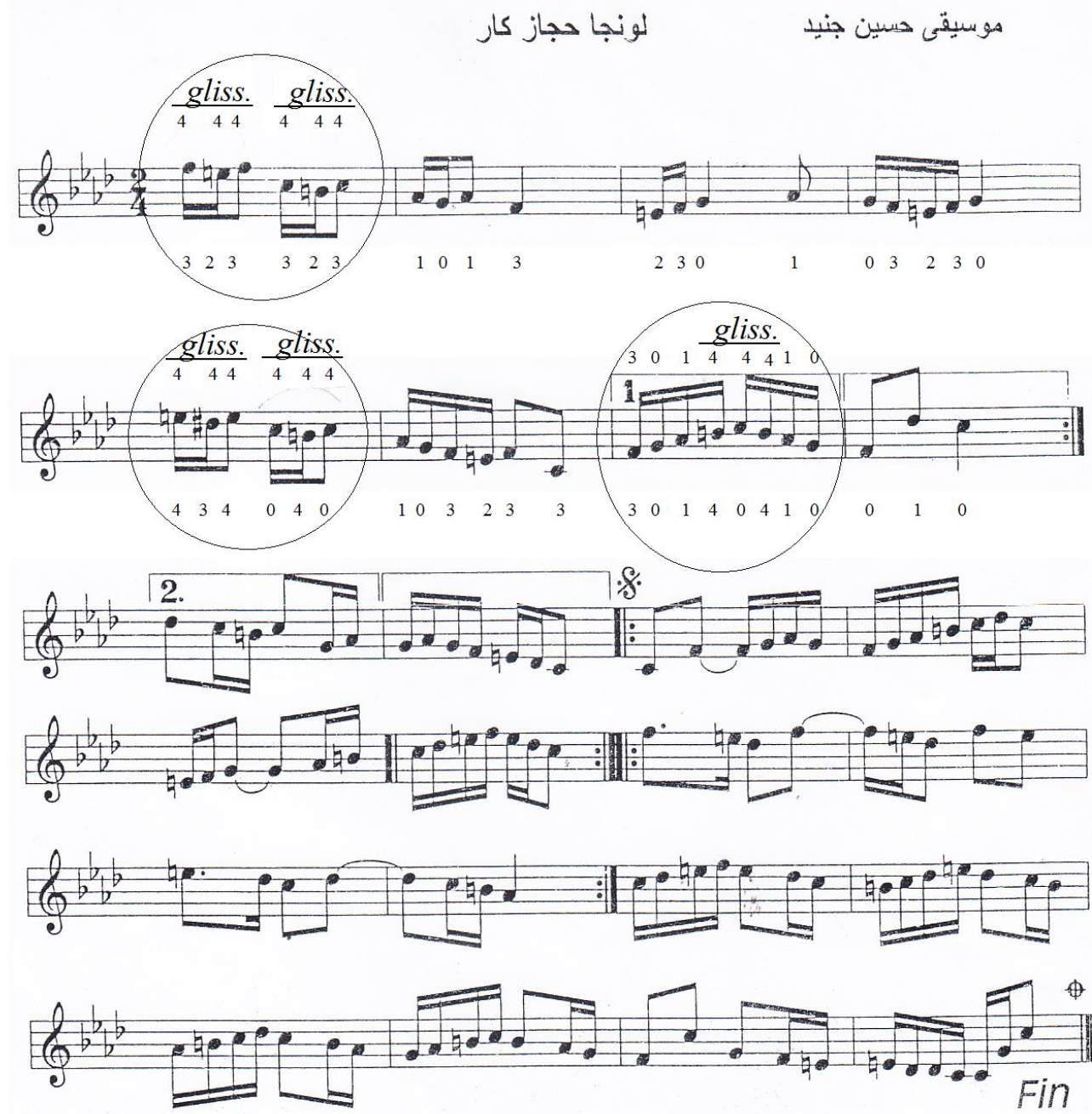

تعليق الباحثة:

ترى الباحثة إمكانية الاستفادة من أداء الزحلقة بالإصبع الر ابع في الخانة الأولى من لونجا حجاز كار (حسين جنيد) على النحو التالي:

- في المازورة رقم (1) يمكن أداء الزحلقةبين نغنتي ( الماهور ان و جو اب البوسليك) على وذي

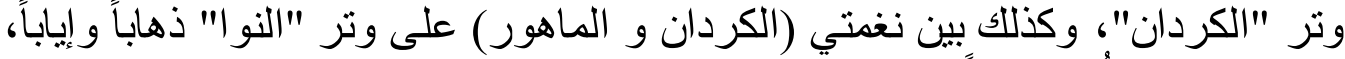

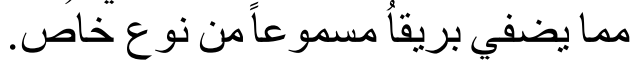

- في المازورة رقم (5) يمكن أداء الزحلقة بين نغمتي (البوسليك و البزرك) على وكي وتر

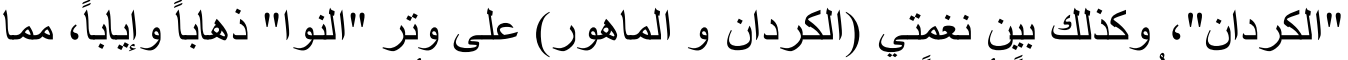

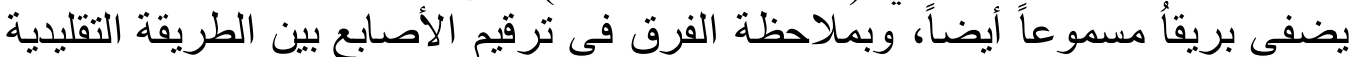

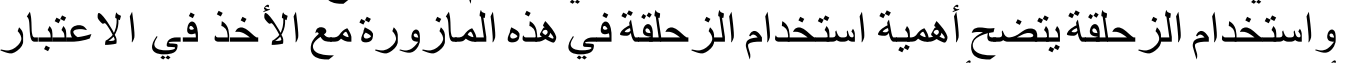

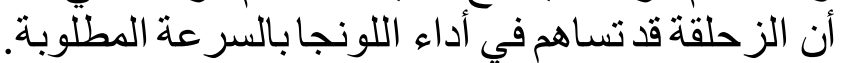


- في المازورة رقم (9) يمكن أداء الزحلقة بين نغني (الماهور و الكردان) ذهاباً وإياباً، على وتر "النو ا"، مما لا يضطر العازف إلى استخداموتر الكردان في هذه الجملة اللحنية

$$
\text { لونجا حجـاز تأليف د. مايسة عبدالغني }
$$
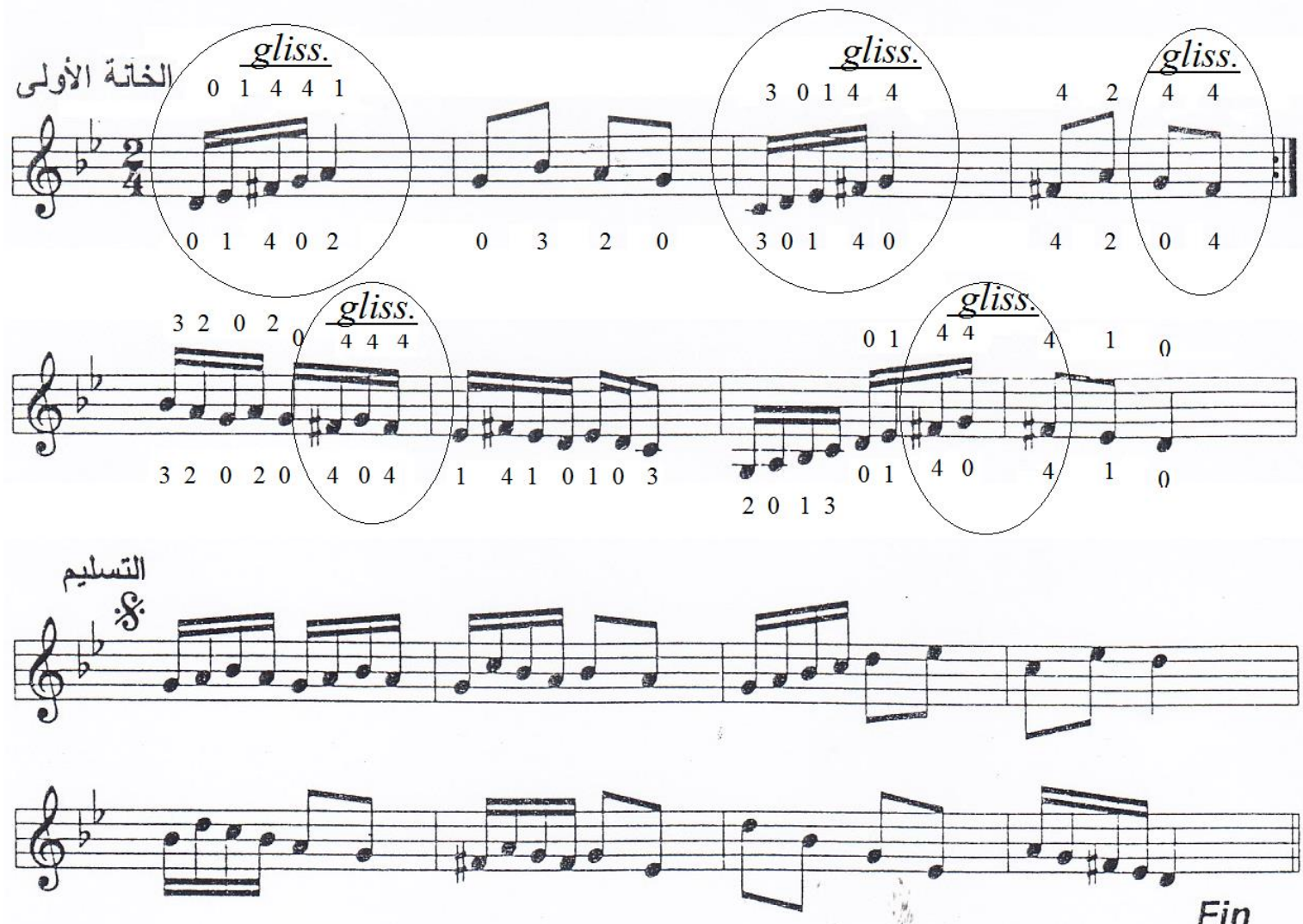

Fin

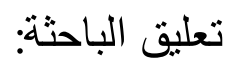

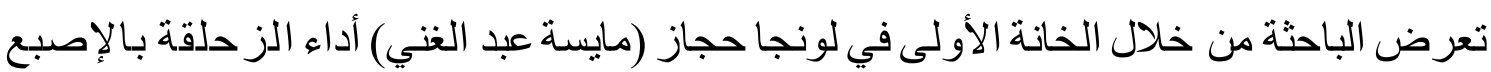

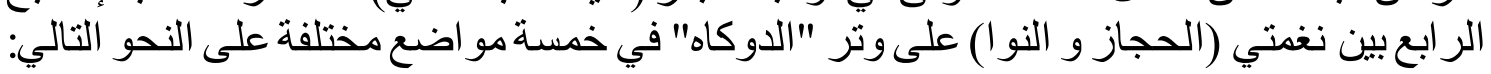

- في المازورة رقم (1) أداء الزحلقةصعوداً بين "الأبُل كروش" الثالث و الر ابع في الذو ار

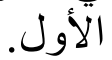

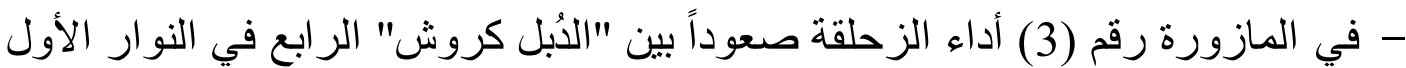

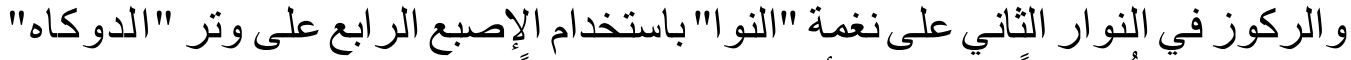

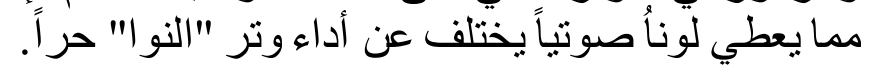

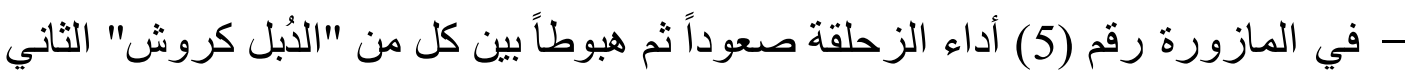

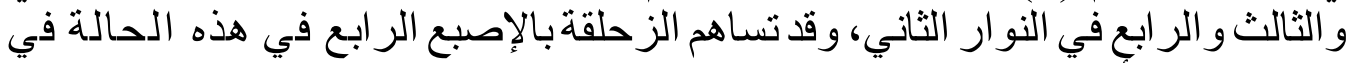

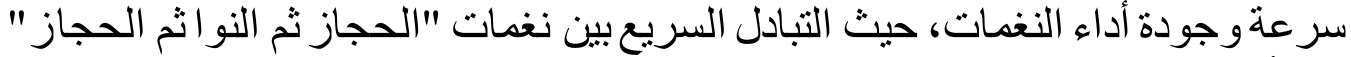

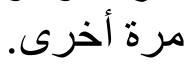




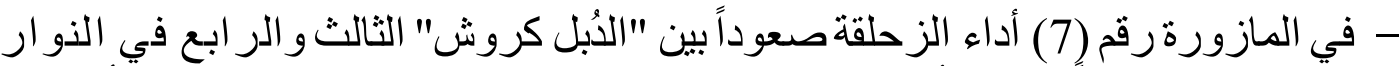

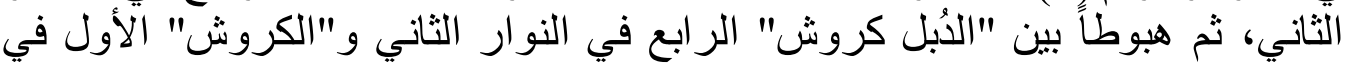

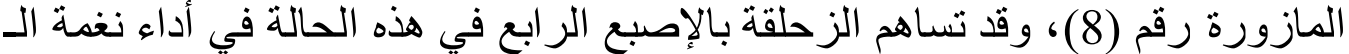

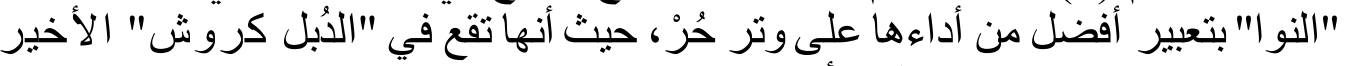
في المازورة رقم (7) مما يتطلب أداء ها بخفوت (piano). نتائج الاراسة: توصلت الباحثة للإجابة على أسئلة البحث على النحو التالي:

1. وضعت الباحثة أربعة تمرينات تكنيكية مقتر حة لتدريب الإصبع الر ابع على مهارة الزحلقة

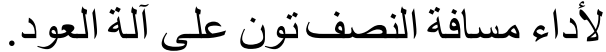

2. وضعت الباحثة سبعة تمرينات لحنية مقترحة تشتمل على مهارة الزحلقة لأداء مسافة النصف تون باستخدام الإصبع الر ابع.

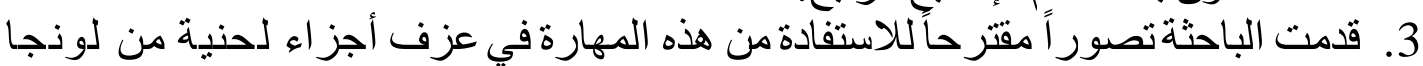

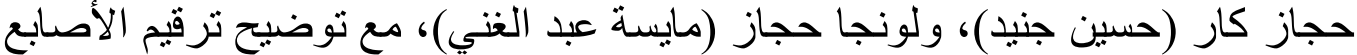
التقليدي و الترقيم الجديد باستخدام الزحلقةبالإصبع الر ابع.

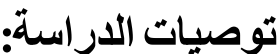

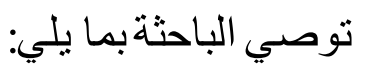

1. تحديث مناهج آلة العود بكلية التربية النوعية بجامعة كفر الثيخ لمو اكبة منطلبات سوق

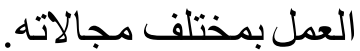

$$
\text { 2. إدداد دارسي آلة العود بالكليات النوعية ببعض أساليب العزف الحديثة. }
$$

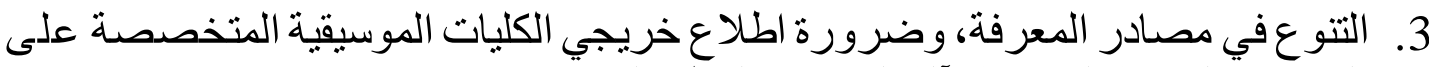
المدارس العزفية المتتوعة لآلة العود في الوطن العربي.

4. متابعة الباحثنين للحركة الإبداعية على الساحة الفنية في مجال العزف على آلة العود، وما يلزمها من تقنيات عزفية حديثة.

5. حث الباحثين على عمل دراسات مماتلةة لتحديث أساليب العزف على مختلف الآلات

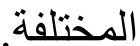

\section{قائمة المراجع و المصادر:}

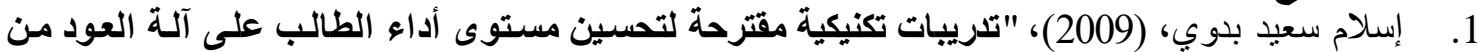

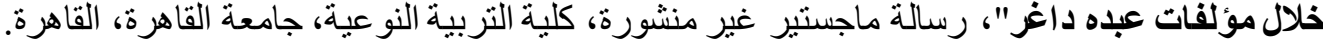
2.

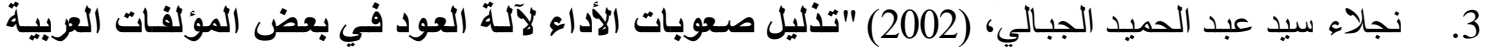

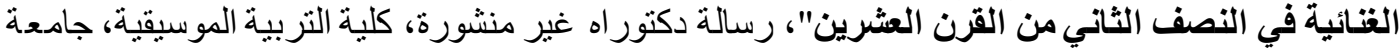
حلوان، القاهرة. 4. سوزان عطية إسماعيل، (1992)، "برنامج تجريبي لرفع مستوى الأداء على آلة العود" رسالة دكتوراه غير منشورة، المعهد العالي للموسيقى العربية، أكاديمية الفنون، القاهرة. 
5. صيانات محمود حمدي، (1978)، "تاريخ آلة العود وصناعته"، دار الفكر العربي، القاهرة.

6.

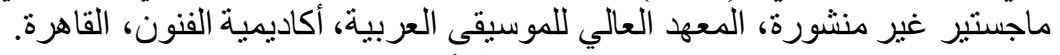

7.

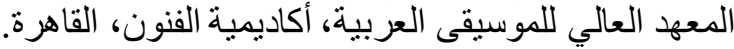

8. محمود أحمد الحفني، (1971)، "علم الآلات الموسيقية"، الهيئة المصرية العامة للتأليف و النشر، القاهية القاهرة. 9.

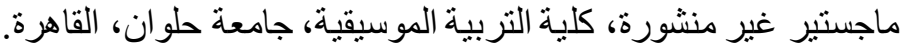
10 ـ نبيل عبد الهادي شوره، (1995)، "الموسيقى العربية (تاريخ- أعلام- ألحان)"، مصرة التهرة للخدمات العلميـة، القاهرة. 